\title{
Potret Pasar Ternak Sumatera Barat
}

\section{The Portrait of Livestock Markets in West Sumatera}

\author{
F. Madarisa ${ }^{1}$, Edwardi $^{2}$, Armadiyan $^{2}$ dan Lazuardi ${ }^{2}$ \\ ${ }^{1}$ Fakultas Peternakan Universitas Andalas, \\ Kampus Unand Limau Manis Padang, 25163 \\ ${ }^{2}$ Dinas Peternakan Provinsi Sumatera Barat Jl. Rasuna Said \\ email: fmadarisa@yahoo.com \\ (Diterima: 10 Juli 2012; Disetujui: 12 September 2012)
}

\begin{abstract}
A survey to understand the profile of livestock market in West Sumatra had been conducted within three months since August to November 2012. The survey had two objectives; (a) to recognize the stakeholders of livestock markets; and $(b)$ to classify the level of livestock market development. Eighteen livestock markets (69.2\%) have responded to fill a distributed questioner from nine districts and municipalities. Collected data were analyzed by using a simple statistical tools as well as descriptive and qualitative approach. The results showed that there were five components of stakeholders with a different role; (1) farmer, (2) farmers group, (3) middlemen, (4) traders and (5) market officers. Livestock markets could be divided into three categories; (a) big market, (b) middle market and (c) small livestock market. Each category has its own indicators. There was a need to improve the livestock market management to anticipate the external and globalization forces. Then it should be a more transparent transaction process in the internal affairs where market process and products are good, standard, healthy and halal. Therefore livestock markets require an improvement of both at their infrastructures and institutional capacity buildings.
\end{abstract}

Key words: livestock market, stakeholders, market process.

\section{PENDAHULUAN}

Kinerja pasar ternak mempengaruhi secara sistemik kondisi, struktur dan kaitan sisi input dan output pasar. Keadaan semacam ini memberi sinyal terhadap daya tarik, semangat beternak dan diseminasi bioteknologi. Disamping itu, kondisi pasar mesti memenuhi kebutuhan dan hak hak konsumen (UU nomor 18 tahun 2009). Misalnya, berupa jaminan pada ketersediaan produk ternak yang aman, sehat, utuh dan halal (ASUH). Dengan demikian pasar ternak mesti terbuka. Jadi, potret pasar perlu dikaji dalam upaya menggairahkan usaha pemeliharaan ternak.

Pasar terbuka adalah pasar yang bisa melindungi kedua sisi, baik produsen maupun konsumen, yaitu perlindungan terhadap eksploitasi harga, informasi keliru, dan ketidakjujuran menakar serta menimbang. Karena itu pasar tidak boleh bersandar pada ego, kebohongan dan korupsi. Maka, pasar perlu mempunyai struktur moral dan keterbukaan. Semua hal ini mesti ditopang oleh kejujuran sosial (Stackhouse dan Stratton, 2002). Besley (1994) merinci beberapa bentuk potensi kemelut pasar (barang dan jasa) yang meminta ketegasan peran pemerintah. Misalnya; kesulitan menegakan aturan, informasi keliru dan tidak merata, dan perbedaan daya beli yang berujung pada potensi monopoli. Seluruh rupa perlindungan ini wajib direncanakan semenjak semula. Dengan demikian pasar ternak membutuhkan perbaikan pengelolaan, agar semua tuntutan kemajuan pasar tercapai.

Dari perspektif akses pasar, terutama bagi peternak miskin, terjadi kegagalan dua pendekatan yaitu; negara dan pasar. Dorward, Farrington dan Deshingkar (2004), mengungkap sulitnya mencapai konsensus antara kedua 
pendekatan, yang melahirkan dua cara pandang. Pertama, kegagalan pasar memerlukan liberalisasi (pembebasan). Hal ini justru menambah biaya dan berpotensi bagi terjadinya korupsi. Bila pasar hendak berjalan efektif, peran intervensi negara mesti dibatasi. Kebijakan ini membutuhkan sarana dan prasarana, legalitas dan kelembagaan pasar serta kelompok peternak yang kuat.

Kedua, 'pasar terkendali' lebih memerlukan kebijakan yang menentang logika pembebasan. Ia membutuhkan lebih banyak koordinasi antara negara dan lembaga terkait lain. Menghapus peran negara, tanpa mengganti dengan peran swasta, menambah dalih buat kegagalan dan penurunan produksi. Disini, peran negara tidak hanya menyediakan jalan, hak penguasaan aset, kesehatan, pendidikan, informasi dan aturan anti monopoli. Negara mesti pula mengatasi resiko, pembangunan modal sosial dan fasilitasi para pihak yang berperan di pasar.

Maka, solusinya berada pada keseimbangan antara pasar yang menghindari diskriminasi non-pasar seperti nilai nilai dan perbedaan jenis kelamin. Kemudian, interaksi patronklien yang menghalangi peternak miskin meraih peluang keluar dari ketergantungan. Dalam konteks Indonesia, negara melalui pemerintah daerah tetap menjalankan peran. Sebab, ini menjadi amanat perundang-undangan.

Faktanya, pasar ternak Sumatera Barat serupa dengan kebanyakan negara berkembang. Pasar ternak ini termasuk tipe priodik, dimana hari pasar hanya sekali atau dua kali seminggu (Ciamarra et al., 2010). Pasar ternak semacam ini amat berbeda satu sama lainnya, lantaran persoalan jarak, kondisi jalan, dan biaya transit. Sehingga, kebijakan pemerintah perlu tertuju kepada; (1). Menilai peluang pengembangan dan keberlanjutan pasar ternak, melalui analisa potensi ternak seputar pasar. (2). Mengidentifikasi lokasi tentang ketersediaan sarana dan prasarana penunjang pasar, seperti; pagar, sumber air, pos kesehatan hewan dll. (3). Tanggung jawab dan penumbuhan kepercayaan kepada pihak swasta dan masyarakat peternak untuk menjalankan pasar, seperti kebersihan, keamanan, pemeliharaan sarana dan prasarana serta pengutipan sewa. (4) Pelayanan pemerintah daerah ketika hari pasar untuk penyuluhan dan vaksinasi, sehingga menarik minat pelaku pasar bertransaksi.

Lebih dari pada itu, implementasi kebijakan dan upaya untuk memperbaiki proses pasar ternak, mesti berpijak pada kondisi nyata lapangan. Para pihak terkait tidak bisa melakukan kegiatan yang aplikatif, tanpa adanya fakta. Apalagi realita, akan berbeda pada tempat dan lokasi yang berlainan. Atas alasan semacam itu, kajian dilakukan.

\section{METODE}

Kajian ini menggunakan metode survey. Kuesioner disusun untuk membantu mengumpulkan data primer. Kemudian, petugas pasar dan Dinas Peternakan Kabupaten / Kota mengisi kuesioner sesuai dengan fungsinya. Ada delapan belas pasar ternak yang telah memberikan jawaban dari sembilan Kabupaten/ Kota. Data sekunder berasal dari laporan Dinas Peternakan Sumbar dan sumber lain yang relevan. Pengolahan data dilakukan dengan bantuan statistik sederhana berupa penjumlahan dan persentase. Sedangkan laporan ditulis dan ditampilkan berupa tabel. Semua ini masuk kategori penyajian deskriptif kualitatif.

\section{HASIL DAN PEMBAHASAN}

\section{Komponen, Sistem dan Proses Pasar}

Sistem pasar ternak Sumatera Barat melibatkan sejumlah pihak. Simak Gambar 1 mengenai sistem pemasaran ternak. Unsur yang bergerak dinamis dan berkiprah dipasar adalah; peternak (1), kelompok peternak (2), toke, yang berfungsi sebagai makelar (3), pedagang (4) dan petugas pasar (5). Aliran proses sesuai dengan arah panah.

Pasar ternak merupakan pusat dari system yang terdiri dari tiga ranah; (a) input (peternak dan kelompok, toke dan pedagang); (b) proses (negosiasi dan transaksi jual beli ternak); (c) output dari pasar berupa aliran ternak menuju tempat pemotongan dan siklus 


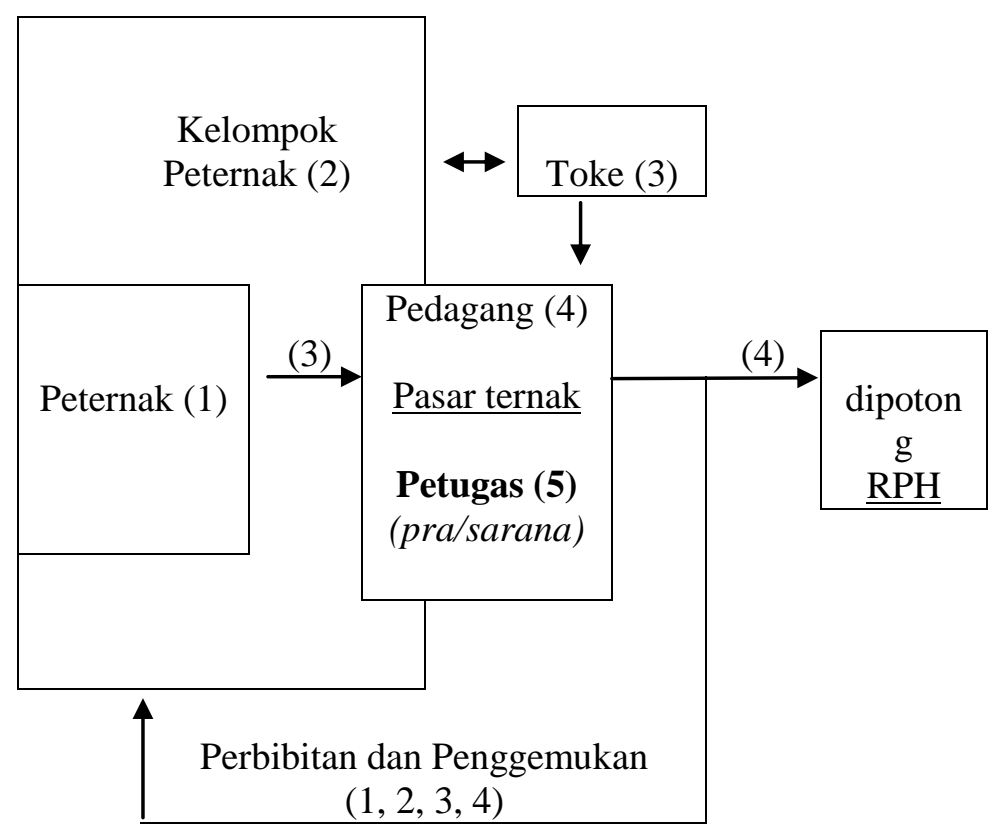

Gambar 1: Sistem dan komponen proses pemasaran ternak di Sumatera Barat.

kembalinya hewan pada peternak untuk dipelihara lagi.

Kelima pihak yang menjalankan fungsi dalam pasar ternak, mempunyai tiga watak. Pertama, watak pemerintah daerah yang dipe rankan oleh petugas pasar (5). Fungsi petugas ialah untuk melayani, melindungi dan mengamankan. Kedua, watak pedagang dan toke (3 dan 4) yang berfungsi mencari untung pada setiap proses transaksi. Ketiga, watak dari peternak dan kelompok (1 dan 2) yang tujuan utamanya tidak saja berusaha. Sebab peternak menjadikan ternak sebagai tabungan guna mengatasi kemelut kehidupan. Akhirnya, beternak merupakan bagian dari sistem pertanian terpadu (interaksi manusia, tanaman, ternak dan lingkungan).

Dari tiga watak pelaku pasar, maka proses pemasaran ternak berjalan dengan tahapan sebagai berikut :

1. Peternak berinteraksi dengan toke atau pedagang untuk melakukan transaksi. Tempat pertemuan tidak saja dipasar ternak resmi, melainkan juga bisa sebelum memasuki pasar, atau lokasi pemeliharaan. Maka, bisa saja pedagang, jika bukan peternak yang membawa ternak ke pasar. Ternak yang memasuki lokasi pasar mesti menunjukan surat bukti kepemilikan yang dikeluarkan oleh walinagari. Surat bukti ialah dasar bagi Petugas, untuk mengeluarkan PAS ternak. Pas ini terdiri dari; (a) surat tentang kesehatan ternak (b) surat retribusi ternak dan (c) ada juga surat bukti jual beli.

2. Toke dan atau pedagang mencermati dan menaksir berat dan atau kandungan daging ternak. Taksiran ini termasuk menatap tingkat kemendesakan peternak untuk menjual.

3. Toke dan pedagang menawarkan harga kepada peternak. Maka, terjadi negosiasi harga. Negosiasi ini bisa pula melalui makelar. Umumnya, saat merundingkan harga ternak, mereka memakai cara tertutup. Atau 'barosok' dibawah kain (sarung). Jejari tangan toke dan pedagang saling memegang. Kedua pihak mengerti proses negosiasi harga yang terjadi. Sehingga timbangan ternak yang ada, tidaklah berguna.

4. Terjadi kesepakatan harga antara penjual dan pembeli. Pembayaran dapat dilakukan di pasar atau berjanji pada kesempatan lain. Di sebagian pasar pengurusan retribusi dilakukan ketika telah terjadi kesepakatan dan transaksi jual beli.

5. Kemudian, ternak dibawa keluar pasar dengan dua tujuan; (a) untuk dijual kembali dan atau dipelihara oleh peternak. 
Umumnya, ternak betina buat diperanakan dan yang jantan untuk penggemukan. (b) ternak yang akan dipotong di RPH atau TPH.

Proses jual beli ini cukup bervariasi pada setiap lokasi pasar. Proses ini perlu standarisasi. Baik untuk langkah kerja, pengurusan surat ternak, besaran dan alokasi retribusi. Tentu hal ini disesuaikan dengan status pasar dan kesepakatan pelaku pasar ternak. Ungkapan Besley (1994); Dorward et al., (2004) atas terjadinya tarik menarik antara pendulum 'pasar dan negara' terjadi ditengah dinamika pasar. Tapi amanat konstitusi menegaskan pemihakan kepada penegakan peran negara dalam proses pasar.

\section{Profil Pasar Ternak.}

Jumlah pasar ternak di Sumatera Barat meningkat menjadi 26 lokasi, pada tahun 2012. Perubahan jumlah pasar ini terjadi di beberapa tempat. Misalnya, (1) pasar Tabek Patah, Salimpaung Tanah Datar. Pasar ternak yang baru ini, khusus menjual-belikan kambing. (2) pasar ternak Mandiangin Koto Selayan di kota Bukittinggi. Pasar ini telah lama berjalan, namun baru masuk dalam catatan.

Kemudian, ada dua pasar ternak yang relatif baru lokasinya dan satu pasar yang terhenti beroperasi. Pasar yang baru ialah; (1) Pasar ternak Padang Siontah (50 Kota) dan (2) pasar ternak Gunung Medan (Dharmasraya). Keduanya telah punya prasarana dan sarana yang memadai, akan tetapi aktivitas pemasaran ternak tersendat, karena pelaku pasar belum menggunakan kedua lokasi bertransaksi, sedangkan pasar ternak yang terhenti beroperasi, ialah Pakandangan (Padang Pariaman).

\section{Lokasi, Hari Pasar dan Jenis Ternak di Pasar}

Di Sumatera Barat tiada hari tanpa pasar ternak. Sebab, pasar ternak beroperasi tujuh hari dalam seminggu. Walaupun lokasi pasar berbeda satu sama lain. Tabel 1 menyajikan kondisi profil pasar yang memuat lokasi, hari pasar dan jenis ternak yang masuk dan keluar dari pasar. Umumnya pasar melayani penju- alan dan pembelian sapi, kerbau dan kambing. Tetapi, ada satu catatan menarik untuk memberikan informasi pasar ternak khusus, seperti; kuda, domba, kambing dan monyet.

Sekalipun begitu, hari pasar paling banyak adalah Kamis (4) pasar, disusul dengan (3) pasar hari Minggu, Senin dan Selasa. Gunung Medan juga hari Kamis, namum belum beroperasi. Kemudian ada dua frekewensi pasar pada hari Rabu dan Sabtu. Pasar Padang Siontah juga hari Rabu, meski belum pula bekerja.

\section{Kapasitas Pasar dan Transaksi Mingguan}

Kecuali pasar ternak Alahan Panjang, semua pasar beroperasi sekali seminggu. Pada Tabel 1 terlihat kapasitas pasar ternak dan transaksi setiap kali hari pasar. Daya tampung pasar ternak Sumatera Barat melebihi angka 8.000 ekor.

Sedang, transaksi sekali pasar sekitar 2.000 ekor. Sehingga jumlah uang yang beredar saat jual beli ternak melebihi angka Rp 11,7 milyar per pekan. Angka ini dihitung dari pasar yang sudah beroperasi.

Dari Tabel 1, terlihat bahwa Pasar Payakumbuh, Palangki, Cubadak dan Muaro Paneh masuk kategori pasar besar. Sebab, keempat pasar omzetnya melebihi 1 milyar setiap kali pasar, dan mempunyai daya tampung lebih dari 500 ekor ternak. Wilayah fungsional pelaku pasar melewati batas administrasi propinsi. Artinya, penjual dan pembeli datang, tidak hanya dari sekitar lokasi, malah dari luar propinsi. Sedangkan pasar kategori sedang beromzet dari Rp. 500 juta sampai 1 milyar per-pekan/ hari pasar. Tiga pasar ternak masuk kategori ini yaitu; pasar Matur Agam, Pasar Kotobaru X Koto Tanah datar dan Pasar Lubuk Basung Agam.

Kapasitas tampung ternak (100-300 ekor) juga sejalan dengan besar omzet ini. Hanya saja ada data yang perlu ditelusuri lebih lanjut. Sebab pasar Limbanang 50 Kota dan pasar Sungai Sariak Padang Pariaman menunjukan angka lebih rendah. Padahal transaksi setiap hari pasar (50-300 ekor) cukup besar. Maka, kedua pasar mestinya masuk ka 
Tabel 1. Kondisi Pasar Ternak di Sumatera Barat

\begin{tabular}{|c|c|c|c|c|c|c|}
\hline \multirow[t]{2}{*}{ No } & \multirow[t]{2}{*}{ Lokasi dan Pengelola Pasar } & \multirow{2}{*}{$\begin{array}{l}\text { Hari } \\
\text { Pasar }\end{array}$} & \multirow{2}{*}{$\begin{array}{c}\text { Jenis ternak } \\
\text { di pasar }\end{array}$} & \multicolumn{3}{|c|}{ Kapasitas Pasar } \\
\hline & & & & $\begin{array}{l}\text { Tampung } \\
\text { (ekor) }\end{array}$ & $\begin{array}{l}\text { Transaksi } \\
\text { (ekor) }\end{array}$ & $\begin{array}{c}\text { Omzet sekali } \\
\text { pasar } \\
\text { (juta } \mathrm{Rp} \text { ) }\end{array}$ \\
\hline 1 & $\begin{array}{l}\text { Pitalah, Jorong Beringin Nagari } \\
\text { Pitalah (Nagari Pita Bunga) } \\
\text { Kecamatan. Batipuh Tanah datar }\end{array}$ & Minggu & $\begin{array}{l}\text { Kambing, } \\
\text { Sapi, Kerbau }\end{array}$ & 100 & 30 & 30 \\
\hline 2 & $\begin{array}{l}\text { Pasar ternak Payakumbuh, kelurahan } \\
\text { Koto Panjang Pyk Timur (Kota } \\
\text { Payakumbuh) }\end{array}$ & Minggu & $\begin{array}{l}\text { Sapi, Kerbau } \\
\text { Kambing }\end{array}$ & 600 & $\begin{array}{l}250 \text { (200 sapi } \\
+50 \text { kambing) }\end{array}$ & 1.650 \\
\hline 3 & Lubuk Basung (Pemda Agam) & Minggu & $\begin{array}{l}\text { Sapi, kerbau, } \\
\text { Kambing }\end{array}$ & 250 & 70 & 560 \\
\hline 4 & $\begin{array}{l}\text { Jorong Tabek Patah, Nagari Tabek } \\
\text { Patah, Tanah datar (Pasar Nagari ) } \rightarrow \\
\text { diluar tanggung jawab Nagari }\end{array}$ & Senin & Kambing & $30-40$ & 41.769 & 41.769 \\
\hline 5 & $\begin{array}{l}\text { Bukit Sundi, jorong Koto Kaciak } \\
\text { Nagari Muaro Paneh Kec. Bukit Sundi } \\
\text { Kab. Solok (pasar Nagari ) }\end{array}$ & Senin & $\begin{array}{l}\text { Sapi, } \\
\text { Kerbau, } \\
\text { Kambing, } \\
\text { Kuda }\end{array}$ & 1,3 & 300 & 2,4 \\
\hline 6 & $\begin{array}{l}\text { Sungai Geringging, (dikontrak oleh } \\
\text { pasar Nagari) Padang Pariaman }\end{array}$ & Senin & Sapi, Kerbau & 300 & 30 & 150 \\
\hline 7 & $\begin{array}{l}\text { Nagari Kotobaru (pemerintah Nagari } \\
\text { kecamatan X Koto T. datar) }\end{array}$ & Selasa & $\begin{array}{l}\text { Sapi dan } \\
\text { kerbau }\end{array}$ & 225 & 75 & 712,5 \\
\hline 8 & $\begin{array}{l}\text { Kumanis, jorong Tanjung raya Nagari } \\
\text { Kumanis Sijunjung }\end{array}$ & Selasa & $\begin{array}{l}\text { Sapi, kerbau, } \\
\text { kambing }\end{array}$ & 70 & 5 & 25 \\
\hline 9 & $\begin{array}{l}\text { Kayu gadang, koto buruak Lubuk } \\
\text { Alung (pasar rakyat) Pdg Pariaman }\end{array}$ & Selasa & $\begin{array}{l}\text { Sapi dan } \\
\text { kerbau }\end{array}$ & 100 & 10 & 60 \\
\hline 10 & $\begin{array}{l}\text { Sungai sariak, kecamatan VII Koto } \\
\text { (Pemda dikelola oleh Nagari Sungai } \\
\text { Sariak) Padang Pariaman }\end{array}$ & Rabu & $\begin{array}{l}\text { Sapi, } \\
\text { Kerbau, } \\
\text { Kambing }\end{array}$ & 1 & $40-60$ & 350 \\
\hline 11 & $\begin{array}{l}\text { Padang aro, Jorong Durian Tarung, } \\
\text { nagari Lubuk Gadang (Sol- Sel) }\end{array}$ & Rabu & $\begin{array}{l}\text { Sapi, kerbau } \\
\text { kambing }\end{array}$ & & 30 & \\
\hline 12 & $\begin{array}{l}\text { Jorong Cubadak, nagari Cubadak } \\
\text { Lima Kaum Tanah datar (Pemda } \\
\text { Tanahdatar) }\end{array}$ & Kamis & $\begin{array}{l}\text { Sapi,kerbau, } \\
\text { kambing, } \\
\text { domba }\end{array}$ & 1 & 300 & 1.880 \\
\hline 13 & $\begin{array}{l}\text { Alahan Panjang, kecamatan Lembah } \\
\text { Gumanti (Pasar Pemda Kab Solok) }\end{array}$ & $\begin{array}{l}\text { Kamis } \\
\& \text { Sabtu }\end{array}$ & $\begin{array}{l}\text { Sapi, kerbau } \\
\text { kambing }\end{array}$ & 100 & 10 & 75 \\
\hline 14 & $\begin{array}{l}\text { Limbanang, jorong Ekor Parit Nagari } \\
\text { Limbanang Kec Suliki (Pemda } 50 \\
\text { kota) }\end{array}$ & Kamis & $\begin{array}{l}\text { Sapi, } \\
\text { Kerbau, } \\
\text { Kambing }\end{array}$ & 500 & 50 & 150 \\
\hline 15 & Pasar Matur (Pemda Agam) & Kamis & Sapi, kerbau & 350 & 50 & $750-900$ \\
\hline 16 & Kotobaru Luhak nan duo (PasBar) & Jumat & Sapi, kerbau & - & - & - \\
\hline 17 & $\begin{array}{l}\text { Palangki IV Nagari, jorong Lintas } \\
\text { Harapan Sijunjung (kontrak Pemda) }\end{array}$ & Sabtu & Sapi, Kerbau & 2 & 600 & 3,6 \\
\hline 18 & $\begin{array}{l}\text { Kampung Dalam, jorong Kpg Tanjung } \\
\text { Nagari Campago (Pasar Nagari) } \\
\text { Padang Pariaman }\end{array}$ & Sabtu & $\begin{array}{l}\text { Sapi, kerbau } \\
\text { kambing, } \\
\text { monyet }\end{array}$ & 120 & 16 & 105 \\
\hline & JUMLAH & & & 8.070 & 1.900 & $11.657,5$ \\
\hline
\end{tabular}

Sumber : Hasil Penelitian (2012) 
tegori sedang. Walau, prasarana dan sarana pendukung operasi pasar pada kategori sedang ini belum memadai, kecuali dipasar Sungai Sariak dan Limbanang.

Kapasitas tampung ternak (100-300 ekor) juga sejalan dengan besar omzet ini. Hanya saja ada data yang perlu ditelusuri lebih lanjut. Sebab pasar Limbanang 50 Kota dan pasar Sungai Sariak Padang Pariaman menunjukan angka lebih rendah. Padahal transaksi setiap hari pasar (50-300 ekor) cukup besar. Maka, kedua pasar mestinya masuk kategori sedang. Walau, prasarana dan sarana pendukung operasi pasar pada kategori sedang ini belum memadai, kecuali dipasar Sungai Sariak dan Limbanang.

Pasar ternak kategori kecil dicirikan dengan beberapa hal, seperti; daya tampung, transaksi dan omzet penjualan satu kali hari pasar. Daya tampung di bawah 100 ekor, transaksi dibawah 50 ekor dan omzet jual beli dibawah $\mathrm{Rp} 500$ juta, masuk kategori ini. Maka delapan pasar menjadi anggota kategori kecil; yaitu; (1) Pitalah dan (2) Tabek Patah di Tanah datar; (3) Sungai Geringging, (4) Lubuak Alung, dan (5) Kampung Dalam di Padang Pariaman. Lalu, pasar (6) Kumanis (Sijunjung), (7) Alahan Panjang (Kabupaten Solok) dan (8) Padang Aro (Solok Selatan). Kondisi sarana dan prasarana pada pasar ternak skala kecil sederhana, sebab pasar ini cenderung tipe pasar tradisional, yang relatif perlu mendapat perbaikan prasarana.

\section{Sarana dan Prasarana Pasar}

Sarana dan prasarana pasar meliputi fasilitas dan infrastruktur untuk menunjang pasar ternak beroperasi. Mestinya, bentuk fasilitas itu tidak saja fisik, melainkan juga non-fisik, seperti lembaga, struktur dan sistem informasi serta akses terhadap pasar. Disamping tiga kategori kapasitas pasar (besar, sedang, kecil) kesediaan sarana dan prasarana di pasar hanya sebatas untuk pasar ternak bekerja secara teknis. Sebab, sarana dan prasarana jalan akses, listrik, dan operasi pengamanan belum disajikan. Begitu pula fasilitas pendukung permodalan, seperti lembaga keuangan mikro (BPR, BRI, LPN atau LKMA).
Sebagai tambahan, sejak pertengahan tahun 2012, sudah terbentuk Asosiasi Pasar Ternak seluruh Sumatera Barat. Asosiasi yang telah memakai akun facebook ini berperan menjadi lembaga untuk menfasilitasi pengelolaan pasar ternak. Sehingga pengelolaan pasar ternak bisa lebih optimal dan berstandar. Struktur asosiasi menyepakati kepala pasar ternak Palangki (Sijunjung) menjadi koordinator. Agustian dari pasar ternak Pasaman Barat menjadi wakil. Sedangkan pelaksana harian Ir. Delmon Horizon (08126758826) dari Bukit Sundi Muaro Paneh Kabupaten Solok. Wakil dari tiap pasar di Kabupaten menjadi anggota Asosiasi itu.

Kesepakatan pendirian asosiasi dan susunan pengurus mencerminkan pula kapasitas fisik, jangkauan jaringan pasar, omzet dan sumberdaya insani pasar ternak itu sendiri. Sehingga pasar ternak bisa lebih berbenah untuk menghadapi masa depan. Tujuannya adalah; (1) upaya mengantisipasi proses globalisasi pasar, (2) perbaikan perlindungan, pelayanan dan keamanan pasar, (3) pemberdayaan masyarakat peternak dan menggairahkan semangat beternak. Jadi uraian Ciamarra, Otte dan Martín (2010) tentang kebijakan pasar ternak negara berkembang umunnya, sebagian besar telah berjalan di Sumatera Barat, melalui aplikasi teknologi komunikasi terakhir.

\section{KESIMPULAN}

Kepekaan perubahan harga di tingkat petani jagung lebih kecil dari kepekaan perubahan harga di tingkat konsumen sehingga pasar kurang efisien. Transmisi harga dari konsumen ke produsen dan sebaliknya dari produsen ke konsumen kurang berjalan dengan baik, karena penumpukan marjin pada pedagang pengumpul sebagai pelaku pasar yang mengendalikan pasar dan menghambat transmisi harga. Petani relatif sedikit mengalami perubahan harga, karena perubahan harga hanya berakibat pada besarnya profit pedagang pengumpul, sehingga petani sendiri se- 
bagai produsen jagung dan peternak ayam ras sebagai konsumen jagung untuk bahan pakan ternaknya tidak diuntungkan dengan kondisi pasar jagung yang ada.

Sejumlah kesimpulan dapat ditarik dari uraian potret pasar ternak Sumatera Barat, yaitu;

1. Jumlah pasar ternak di Sumatera Barat meningkat menjadi 26 lokasi pada tahun 2012. Peningkatan jumlah ini ditandai dengan adanya pasar ternak yang relatif baru, seperti Padang Siontah, Gunung Medan dan Tabek Patah serta Kotobaru Luhak Nan Duo Pasaman Barat. Hanya saja ada pasar ternak yang belum beroperasi optimal (Padang Siontah dan Gunung Medan) dan yang terhenti beroperasi (Pakandangan).

2. Pasar ternak Sumatera Barat termasuk pasar yang belum sepenuhnya berstandarisasi. Meskipun peran pemerintah diwajibkan oleh aturan, tarik menarik kepentingan dan dinamika antar pelaku pasar masih kuat. Sehingga upaya penegakan aturan yang lebih terbuka menemui kesulitan dalam pelaksanaannya.

3. Pasar ternak Sumatera Barat termasuk pasar priodik yang beroperasi sekali (dua kali) dalam seminggu. Pasar ternak ini terbagi kedalam tiga kategori; besar, sedang dan kecil. Tiap kategori mempunyai ukuran sebagai berikut;

a. Pasar ternak kategori besar; (1) omzet penjualan ternak dalam satu kali hari pasar di atas Rp 1 milyar, (2) Kapasitas daya tampung pasar diatas 500 ekor, (3) Transaksi jual beli ternak diatas 300 ekor, dan (4) Sarana dan prasarana untuk mendukung operasi pasar mencukupi. Terdapat empat pasar yang masuk kategori besar, yaitu; Kota Payakumbuh; Cubadak, Tanah datar, Muaro Paneh Bukit Sundi Kabupaten Solok dan Palangki, di Sijunjung.

b. Pasar ternak kategori sedang; (1) omzet penjualan ternak dalam satu kali hari pasar antara Rp 500 juta sampai Rp 1 milyar, (2) Kapasitas daya tampung ternak antara 100-300 ekor, (3) transaksi jual beli ternak antara 50 sampai 300 ekor, dan (4) Sarana dan prasarana penunjang operasi pasar belum memadai. Ada lima pasar ternak masuk kategori sedang, yaitu; pasar Matur Agam, Pasar Kotobaru X Koto Tanah datar dan Pasar Lubuk Basung Agam. Lalu, pasar Limbanang 50 Kota dan pasar Sungai Sariak Padang Pariaman.

c. Pasar ternak kategori kecil dan tradisionil; (1) omzet penjualan di bawah Rp 500 juta setiap kali hari pasar, (2) Kapasitas daya tampung ternak dibawah 100 ekor, (3) transaksi jual beli ternak dibawah 50 ekor, dan (4) Sarana dan prasarana masih sederhana dan relatif belum mendapat perbaikan. Delapan pasar masuk kategori ini, yaitu; (1) Pitalah dan (2) Tabek Patah di Tanah datar; (3) Sungai Geringging, (4) Lubuak Alung, dan (5) Kampung Dalam di Padang Pariaman. Kemudian pasar (6) Kumanis (Sijunjung), (7) Alahan Panjang di Kabupaten Solok dan (8) Padang Aro (Solok Selatan).

4. Umumnya pasar memperjualbelikan tiga jenis ternak; sapi, kerbau dan kambing. Hari pasarnya berlangsung dari Minggu sampai Sabtu. Tapi ada pasar ternak keperluan khusus, seperti monyet di Kampung Dalam Padang Pariaman (Sabtu), domba di Cubadak Tanah datar (Kamis), Kambing di Tabek Patah Tanah datar (Senin) dan kuda di Muaro Paneh di Kabupaten Solok (Senin).

Saran perbaikan bagi peningkatan mutu pengelolaan pasar ternak ialah :

1. Perbaikan pengelolaan pasar ternak membutuhkan standarisasi yang sejalan dengan peningkatan tekad serta kapasitas petugas pelaksana.

2. Sistem pengelolaan pasar yang terbuka dan memberi jaminan produk ASUH perlu informasi dan prosedur keluar-masuknya ternak dari pasar, yang berlaku bagi semua pasar ternak Sumatera Barat.

3. Perbaikan kelengkapan sarana dan prasarana untuk menunjang operasi dan aktivitas pasar, lebih ditujukan kepada pasar kategori sedang dan kecil. Perbaikan keleng- 
kapan pasar ternak ini termasuk peningkatan mutu fasilitas seperti jalan ke pasar dan akses pada lembaga keuangan.

\section{UCAPAN TERIMA KASIH}

Terima kasih kepada pengelola pasar ternak dari seluruh Sumatera Barat, yang telah memberikan informasi melalui pengisian kuisioner.

\section{DAFTAR PUSTAKA}

Besley, Timothy. 1994. How Do Market Failures Justify Interventions in Rural Credit Markets?. The World Bank Research Observer, Vol. 9, No. 1 (Jan., 1994), pp. 27-47. Published by: Oxford University Press Stable URL: http://www.jstor.org/stable/3986548.

Accessed: 01/11/2010 12:23.
Ciamarra, Ugo Pica; Joachim Otte dan Chiara Martín. 2010. Livestock Sector Policies and Programmes in Developing Countries. A Menu for Praticioners. FAO. Rome.

Dorward, Andrew; John Farrington dan Priya Deshingkar. 2004. Making agricultural markets work for the poor. Working Paper for the Renewable Natural Resources and Agriculture Team, DFID Policy Division. London.

Madarisa, F. 2010. Perspektif Sosiologi Pembangunan Agribisnis. Fakultas Peternakan Universitas Andalas. Padang.

Stackhouse, Max dan Lawrence M. Stratton, 2002. Capitalism, Civil Society, Religion, and the Poor: A Bibliographical Essay. Intercollegiates Institute Wilmington. Delaware 